\title{
PENGARUH RISIKO KREDIT DAN TINGKAT KECUKUPAN MODAL TERHADAP PROFITABILITAS PERBANKAN YANG LISTING DI BEI PERIODE 2015-2019
}

\author{
Kiki Nadillah \\ Program Studi Manajemen Sekolah Tinggi Ilmu Ekonomi (STIE) Bima \\ kikinadillah17.stiebima@gmail.com \\ Puji Muniarty \\ Program Studi Manajemen Sekolah Tinggi Ilmu Ekonomi (STIE) Bima \\ puji.stiebima@gmail.com
}

\begin{abstract}
Abstrak: Pengaruh Risiko Kredit Dan Tingkat Kecukupan Modal Terhadap Profitabilitas Perbankan Yang Listing Di BEI Periode 2015-2019. Penelitian bertujuan untuk mengetahui pengaruh Risiko Kredit dan Tingkat Kecukupan Modal Terhadap Profitabilitas Perbankan yang Listing Di BEI Periode 2015-2019 dan ada 43 perbankan listing di BEI. Sample diambil 10 perusahaan perbankan. Teknik sampling yang digunakan purposive sampling. Data di analisis dengan analisis risiko kredit, analisis tingkat kecukupan modal, analisis profitabilitas, uji asumsi klasik, uji parsial dan uji serempak. Secara parsial dan serempak hasil menunjukan resiko kredit dan tingkat kecukupan modal berpengaruh signifikan terhadap profitabilitas. sedangkan secara serempak menyatakan bahwa ada pengaruh yang signifikan resiko kredit dan tingkatkan kecukupan modal terhadap profitabilitas.
\end{abstract}

Kata kunci: Profitabilitas, Risiko Kredit, Tingkat Kecukupan Modal.

Abstract: Effect of Credit Risk and Capital Adequacy Levels Profitability of Banks Listing on the IDX for the 2015-2019 Period. This study aims to determine the effect of Credit Risk and Capital Adequacy Level on the Profitability of Banks Listed on the IDX for the 2015-2019 period, and there are 43 banks listed on the IDX. Samples were taken from 10 banking companies. The sampling technique used was purposive sampling. The data were analyzed by credit risk analysis, capital adequacy level analysis, profitability analysis, classical assumption test, partial test and simultaneous test. Partially and simultaneously the results show that credit risk and the level of capital adequacy have a significant effect on profitability. while simultaneously stating that there is a significant effect of credit risk and increasing capital adequacy on profitability.

Keywords: Profitabilitas, Credit Risk, Capital Adequacy Level.

\section{PENDAHULUAN}

Pada pengembangan perekonomian dizaman sekarang industri bank tidak dapat diragukan lagi dampaknya. Bank juga sangat vital untuk perkembangan ekonomi oleh sebab itu totalitas dari suatu jaringan prosedur keuangan di mayoritas perekonomian secara global dipengaruhi pada sistem perbankan. Bank memiliki peran utama dalam berkembangnya ekonomi negeri, serta terdapatnya dana sangat diperlukan untuk pembangunan di sesuatu negeri. Secara spontan ataupun tidak bank sudah banyak menjalankan beraneka macam aktivitas ekonomi negeri (Pratiwi, 2016). Adapun aktivitas pokok perbankan terdiri atas menghimpun dana dari masyarakat luas dan menyalurkan dana ke berbagai pihak yang membutuhkan.

Persaingan antar bank menunjukkan performa dalam mempengaruhi nasabah untuk menabung. Sumber pendapatan bank tidak bisa 
terlepas dari saving, deposito dan giro. Ketiga komponen tersebut memiliki peran masingmasing dalam mendapatkan dana segar untuk dikelola lebih lanjut oleh bank sehingga menjadi sumber pendapatan.

Perbankan merupakan bisnis pengambilan resiko. Bank biasanya melaksanakan peran intermediasi dengan mendapatkan simpanan dari nasabah serta memberikan pinjaman uang kepada debitur. Dalam melaksanakan hal tersebut, mereka akan dihadapkan dengan bermacam-macam resiko, tentunya secara langsung serta/ ataupun tidak langsung dapat berpengaruh pada profitabilitas mereka. A core business of banks is credit provision, from which they generate profit. In this business, credit risk is one of their primary hurdles. Indicated that credit quality is a fundamental indicator of any bank's financial soundness and health. Since credit creation is the main income generating activity of a bank, poor credit or loan quality contributes enormously to bank failures (Mendoza \& Rivera, 2017).

Adapun menurut Edy (2019) fenomena yang terjadi sebelum covid pada dimana Non Performing Loan (NPL) bank di quarter 42019 meningkat. Bank Indonesia menuliskan, per Oktober 2019 kedudukan NPL telah menerobos 2,73\% menurut gross. Kedudukan meningkat daripada bulan sebelumnya yang mencatat 2,66\%. Kedudukan NPL pada bulan Oktober 2019 menjadi level tertinggi sejauh tahun. Serta apabila merujuk terhadap analisa yang diringkas CEIC Data, NPL Indonesia termasuk cukup tinggi daripada negara tetangga pada bulan September-Oktober 2019. Dimana, Filipina menuliskan NPL pada level $2,2 \%$, Malaysia mencatat NPL seimbang pada $1,6 \%$, kemudian Singapura mencantumkan NPL 1,3\% serta Vietnam 2\%. serta, Thailand mencantumkan NPL lebih besar daripada Indonesia yaitu mencapai 3\% pada September 2019 sehingga bisa disimpulkan bahwa kedudukan NPL di Indonesia tidak jauh lebih baik dari negara Filipina, Malaysia Singapura dan Vietnam.

Bank yang terdaftar di BEI tidak terlepas dari kredit bermasalah dan pengeluaran biaya yang tinggi menunjang aturan OJK dengan kebijakan-kebijakan yang dikeluarkan. Bank sebagai badan usaha bank dituntut untuk memaksimalkan profit dan tentunya posisi Capital Adequacy Ratio (CAR) indicator terpenting yang dapat memaksimalkan keuntungan bank (Edy, 2019).

CAMEL adalah aspek yang paling banyak berpengaruh terhadap kondisi keuangan bank yang mempengaruhi pula tingkat kesehatan bank. Oleh sebab itu, analisis CAMEL menjadi tolak ukur pemeriksaan bank yang dilakukan oleh pengawas bank dalam menentukan tingkat kesehatan dan kinerja setiap perusahaan perbankan. Rasio-rasio CAMEL mampu menggambarkan suatu hubungan antar-akun dalam laporan keuangan yang sekaligus menunjukkan baik buruknya kondisi 
atau posisi keuangan suatu bank. Bank yang sehat pastinya dapat memberikan layanan finansial yang baik kepada masyarakat, baik dalam hal menjamin keamanan dana simpanan maupun penyalurannya ke masyarakat dalam bentuk pinjaman. Rasio CAMEL dan proksi yang digunakan dalam penelitian ini terdiri dari NPL, CAR dan ROA. Rasio NPL (NonPerforming Loan) digunakan untuk mengukur Asset Quality dengan perhitungan aset kredit bermasalah dibagi total kredit, rasio CAR (Capital Adequacy Ratio) digunakan untuk mengukur Capital Adequacy dengan perhitungan modal sendiri (ekuitas) dibagi total aktiva, ROA (Return On Asset) menunjukkan perbandingan laba sebelum pajak dengan aset.

Berikut hasil pengamatan pada performa keuangan perbankan yang listing di BEI yang berupa rasio NPL, CAR dan ROA dari tahun 2015-2019 yang dipaparkan menggunakan grafik pergerakan rasio.

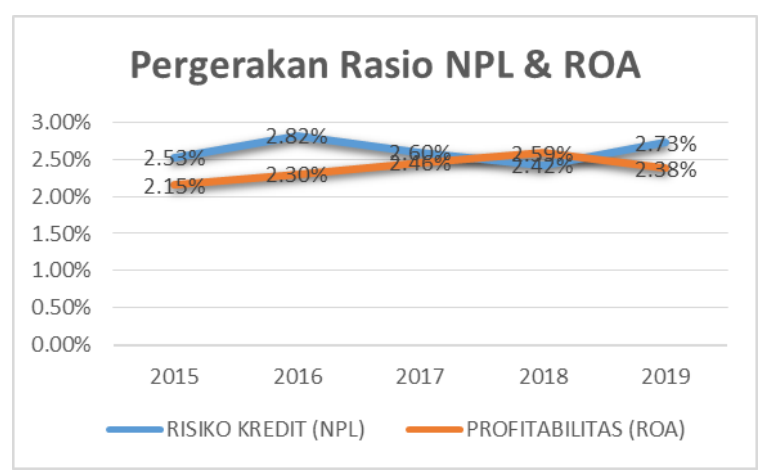

Gambar 1: Pergerakan NPL dan ROA

Berdasarkan gambar 1 pergerakan NPL dan ROA , terlihat bahwa posisi pergerakan NPL tidak stabil akan tetapi NPL pada gambar grafik tersebut sudah sesuai dengan kriteria yang ditetapkan Bank Indonesia yaitu 5\% dimana apabila diatas $5 \%$ bisa dikatakan tidak baik. Kemudian presentase ROA sendiri juga sudah sesuai dengan standar yang di keluar Bank Indonesia yaitu sebesar 1,5\%.

Namun yang perlu diamati ialah data antara NPL dan ROA pada tahun 2015-2016 dimana nilai presentase NPL pada tahun tersebut terjadi kenaikan yang diikuti dengan meningkatnya ROA. Pada gambar diatas menunjukan nilai NPL pada tahun 2015 sebesar 2,53\% menjadi 2,82\% serta dengan tahun yang sama nilai ROA dari 2,15\% menjadi 2,30\%. Hal ini jelas tidak selaras terhadap konsep yang ada, sebab NPL menggambarkan risiko kredit, dimana semakin besar presentase NPL mengakibatkan semakin tinggi pinjaman bunga kredit yang tentunya akan berpotensi menurunnya suatu pendapatan bunga serta menurunkan profit. Tingkat kolektibilitas bank yang tinggi akan berdampak pada multiplayer effect bagi earning power, sebab earning power kunci dari kredibilitas manajemen bank.

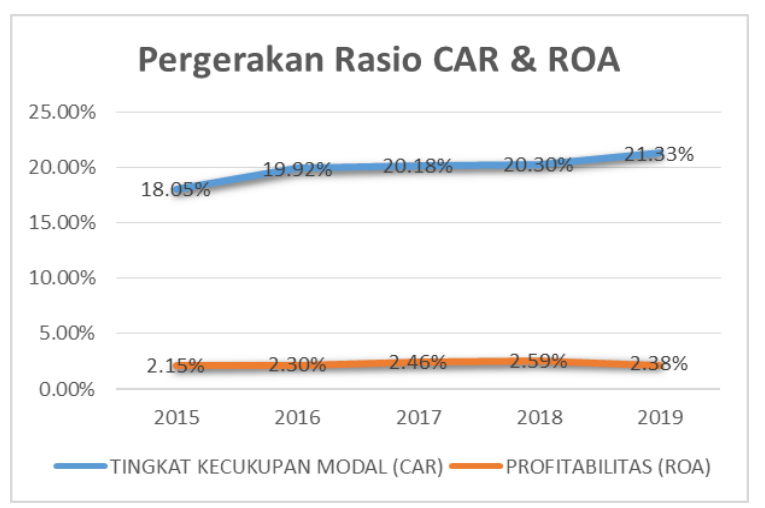

Gambar 2: Pergerakan CAR dan ROA 
Berdasarkan gambar 2 pergerakan CAR dan ROA menggambarkan bahwa performa keuangan CAR pada tahun 2015-2019 terjadi suatu peningkatan. Akan tetapi pada tahun 2018-2019 terjadinya penurunan ROA yang tidak diikuti dengan menurunnya performa CAR. Meningkatnya CAR di tahun 2019 senilai $21,33 \%$ tidak sejalan dengan meningkatnya ROA, yang terlihat pada grafik tersebut bahwa nilai ROA pada tahun 2018 sebesar $2,59 \%$ turun menjadi $2,38 \%$ pada tahun 2019. Realita ini tentu berbeda dengan teori yang dimana performa CAR terdapat pengaruh positif terhadap ROA, artinya semakin tinggi CAR maka profit bank juga semakin besar. Sebaliknya semakin kecil risiko pada bank maka semakin besar profit yang didapatkan bank.

Penelitian yang dilakukan Herlina et al., (2016) menunjukkan variabel risiko kredit yang diukur dengan Non Performing Loan memiliki pengaruh negatif terhadap profitabilitas yang diukur dengan ROA, artinya apabila risiko kredit meningkat maka tingkat profitabilitas akan menurun begitu pula sebaliknya apabila risiko kredit menurun maka profitabilitas meningkat. Penelitian ini menemukan pengaruh positif antara rasio kecukupan modal terhadap profitabilitas bank baik secara langsung maupun tidak langsung melalui risk taking behavior. Semakin besar rasio kecukupan modal yang dimiliki oleh suatu bank maka profitabilitasnya juga akan semakin besar. Selain itu, penelitian ini juga menentukan bahwa bank yang memiliki rasio kecukupan modal yang besar cenderung menjadi risk taker guna memperoleh keuntungan yang lebih besar (Sinaga, 2019). Berdasarkan paparan diatas perlu dilakukan penelitian lebih lanjut dan mendalam lagi tentang NPL, CAR, dan ROA yang akan dibahas lebih tajam dalam penelitian ini khususnya bank yang listing di Indonesian Stock Exchange periode 2015-2019.

\section{KAJIAN LITERATUR}

\section{Risiko Kredit}

Risiko kredit merupakan suatu risiko yang mungkin timbul akibat gagalnya pengembalian sebagai kredit yang diberikan dan menjadi kredit bermasalah sehingga mempengaruhi pendapatan bank (Firdaus \& Maya, 2009).

Risiko kredit adalah dampak dari suatu penyaluran kredit terhadap debitur yang tidak sanggup mengangsur dalam kurun waktu yang sudah diberikan. Apabila bank itu sendiri tidak memberi kredit terhadap nasabahnya maka bank tersebut tidak akan memperoleh keuntungan atau profit yang berasal dari kredit tersebut (Pratiwi, 2016), sehingga keuntungan yang didapatkan perusahaan bisa digunakan untuk sumber modal bank itu sendiri. Akan tetapi apabila kredit menghadapi suatu kegagalan seperti debitur tidak bisa membayar kewajibannya pada kurun waktu yang sudah ditentukan ,secara langsung hal tersebut dapat 
menghambat pemasukan laba perusahaan yang menyebabkan terjadinya masalah akuntansi.

Risiko kredit dapat dihitung dengan NPL sebab NPL merupakan kondisi dimana nasabah telah tidak sanggup untuk membayar sebagian ataupun segala kewajiban kepada bank semacam yang sudah dijanjikan sejalan dengan ikatan perjanjian kredit. NPL digunakan untuk mengukur seberapa jauh kredit bermasalah. NPL juga ialah rasio untuk memperkirakan kemampuan bank dalam melindungi risiko kegagalan mengembalikan suatu pinjaman pada debitur. Adapun NPL dinyatakan dalam rumus berikut:

$$
\mathrm{NPL}=\frac{\text { KREDIT MACET }}{\text { TOTAL KREDIT }} \times 100 \%
$$

2. Tingkat Kecukupan Modal

Tingkat kecukupan modal yang mencukupi bisa menjaga bank saat menghadapi suatu resesi dari kegiatan operasional yang tak bisa diprediksi atau yang tak sengaja. Kecukupan modal ialah rasio yang memilki suatu tujuan untuk meyakinkan dimana bank bisa menyerap kerugian yang disebabkan dari kegiatan yang dilakukan bank tersebut (Anjani \& Purnawati, 2014).

Sebagaimana pantasnya suatu lembaga usaha, modal bank patut untuk digunakan dalam melindungi kemungkinan berlangsungnya risiko kerugian yang berdampak dalam pergerakan aktiva bank yang dimana sebagian besar bersumber dari dana masyarakat (Septiani \& Lestari, 2016). Kecukupan modal dalam hal ini diproksikan dengan CAR dimana CAR digunakan untuk indikator utama suatu keahlian bank dalam menutupi turunnya aktiva yang disebabkan oleh kerugian yang dialami bank itu sendiri (Said, 2016). Tinggi rendahnya CAR dapat ditetapkan pada keahlian bank dalam memperoleh keuntungan dan pendistribusian dana pada aktiva sesuai dengan tingkat risiko yang dialami. CAR ialah rasio yang terdiri dari total modal sendiri terhadap aktiva tertimbang menurut risiko (ATMR).

CAR dapat dinyatakan dalam rumus berikut:

$\mathrm{CAR}=\frac{\text { MODAL SENDIRI }}{A T M R} \times 100 \%$

3. Profitabilitas

Profitabilitas ialah faktor terpenting dalam kesehatan bank, oleh sebab itu profitabilitas bisa membantu keberhasilan bank dengan meminimalkan kewajiban dalam kurun waktu yang cukup lama.

Profitabilitas ialah keahlian suatu bank dalam memperoleh profit dari semua aktivitas bank itu sendiri, dalam hal ini bentuk presentase yang bisa dilihat dengan salah satu komponen yaitu ROA (Said, 2016). Dimana ROA digunakan sebagai proksi untuk menghitung profitabilitas perbankan sebab ROA ialah rasio terpenting bagi bank serta rasio tersebut digunakan sebagai alat ukur efektivitas bank ketika menghasilkan profit dengan memanfaatkan segala aktiva yang dimiliki perusahaan. Pengukuran profitabilitas ini tentunya menggunakan ROA (Pratiwi, 
2016). Adapun Rumus ROA dapat dinyatakan sebagai berikut:

$\mathrm{ROA}=\frac{\text { laba sebelum pajak }}{\text { TOTAL ASET }} \times 100 \%$

4. Pengaruh Risiko Kredit Terhadap Profitabilitas.

Risiko Kredit tentunya memiliki kaitan terhadap profitabilitas, sebab meningkatnya menyebabkan tingginya kolektibilitas yang dimana menimbulkan dampak tidak lancarnya pengembalian kredit sesuai jangka waktu tempo. Akibat yang muncul dari hal tersebut ialah tidak didapatkannya keuntungan lewat kredit itu sendiri, maka risiko kredit ini bisa menyebabkan menurunnya profitabilitas perbankan. Risiko kredit ini tentunya menggunakan NPL dimana resiko kredit memiliki pengaruh negatif terhadap profitabilitas (Negara et al., 2014), resiko kredit memiliki pengaruh negatif terhadap profitabilitas.

5. Pengaruh Tingkat Kecukupan Modal Terhadap Profitabilitas.

Korelasi CAR terhadap ROA dapat digunakan sebagai kepentingan stakeholder guna membangun bisnis dengan berbagai skala usaha dan menutupi risiko dengan berbagai kemungkinan yang akan terjadi, posisi CAR yang tinggi merupakan sumber penilaian performa bank guna menarik debitur untuk menyimpan dana di bank tentu dana akan di kelola secara maksimal melalui pinjaman. Serta kredit yang akan disalurkan/ dipinjamkan kepada masyarakat kelak akan didapatkan bunga, dengan bunga tersebut maka akan didapatlah keuntungan suatu perusahaan (Anggreni \& Suardhika, 2014).

Tingkat kecukupan modal dihimbau pada penelitian yang dahulu bahwa performa kecukupan modal memiliki pengaruh terhadap performa profitabilitas.

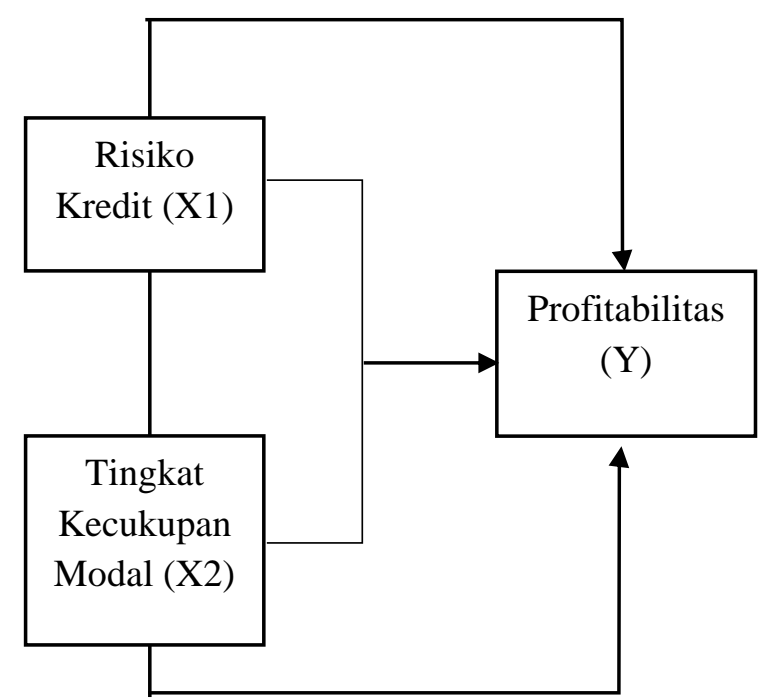

Gambar 3: Bagan Teoritis

Berdasarkan kajian teoritis dan penelitian terdahulu yang telah dikemukakan tersebut, Adapun gambar 3 menjelaskan hipotesis dalam penelitian ini yang kemudian dapat dirumuskan sebagai berikut:

H1: Ada pengaruh dan signifikan secara parsial Risiko Kredit terhadap Profitabilitas.

H2: Ada pengaruh dan signifikan secara parsial Tingkat Kecukupan Modal terhadap Profitabilitas.

H3: Ada pengaruh dan signifikan secara simultan Risiko Kredit dan Tingkat Kecukupan Modal terhadap Profitabilitas.

H4: Risiko kredit berpengaruh dominan terhadap profitabilitas. 


\section{METODE PENELITIAN}

\section{Jenis Penelitian}

Penelitian ini mengacu pada hubungan asosiatif kausal tentunya hal ini menunjukkan hubungan yang sifat sebab akibat dengan menunjukkan adanya variabel independen/ variabel yang mempengaruhi dan variabel dependen/ variabel yang dipengaruhi (Suharsimi, 2006). Penelitian ini dilakukan untuk mencari hubungan antara NPL dan CAR terhadap ROA perbankan yang listing di BEI periode 2015-2019.

\section{Waktu dan Tempat Penelitian}

Objek penelitian di Indonesia Stock Exchange Building yang melalui akses data www.idx.com terdiri atas laporan keuangan perusahaan yang teraudit sebagai sumber pengambilan

\section{Subjek Penelitian}

Populasi pada penelitian ini terdiri dari 43 perusahaan perbankan yang terdaftar di BEI. Serta adapun sampel yang diambil pada penelitian ini ialah 10 perusahaan perbankan yang terdaftar di BEI periode 2015-2019. Sampling yaitu purposive sampling dimana pertimbangannya berupa; 1). Perusahaan sudah melaporkan laporan keuangan dalam kurun waktu 5 tahun belakangan 2). Bank yang update laporan keuangan per periode Perusahaan mempunyai laporan tahunan yang berakhir 31 desember. 3). Ketersediaan data mengenai variabel penelitian. 4). Bank yang termasuk dalam pemilik aset terbesar. 5). Bank pemilik aset diatas 153 triliun rupiah.

\section{Instrumen Penelitian.}

Instrumen penelitian ialah keputusan terpenting dalam bentuk tata cara penelitian. Instrumen tentunya berguna untuk suatu alat topang dalam mengumpulkan data yang diinginkan (Siyoto \& Sodik, 2015). Bentuk instrumen berkaitan dengan metode pengumpulan data. Instrumen pada penelitian ini ialah tabel berupa rasio keuangan bank yang terdaftar di BEI periode 2015-2019, dimana terdiri dari performa keuangan perbankan yaitu NPL, CAR serta ROA.

\section{Teknik Analisa Data}

Menggunakan sumber data sekunder berbentuk finansial report bank yang listing di BEI melalui website www.idx.com, studi literatur dan dokumentasi. Data yang digunakan dalam penelitian ini data time series yang ditabulasi selama ke dalam daftar tabel dan diuji dengan menggunakan teknik analisa uji asumsi klasik, regresi linear berganda ,uji parsial dan uji simultan (Sugiono, 2016).

\section{HASIL PENELITIAN DAN PEMBAHASAN}

\section{Pembahasan Uji Parsial dan Uji Simultan}

H1 diterima dimana nilai sig 0,000 lebih kecil dari 0,05 artinya ada pengaruh yang signifikan secara parsial antara NPL terhadap ROA penelitian ini sejalan dengan penelitian yang dilakukan oleh Herlina et al. (2016) 
dimana nilai sig 0,029 lebih kecil dari tingkat signifikan sebesar 0,05 , sehingga risiko kredit memiliki pengaruh terhadap profitabilitas.

Tabel 1: Hasil Uji Parsial

\begin{tabular}{lccc}
\hline \multicolumn{1}{c}{$\begin{array}{c}\text { Variable } \\
\text { Bebas }\end{array}$} & $\begin{array}{c}\text { Variable } \\
\text { Terikat }\end{array}$ & t & Sig. \\
\hline $\begin{array}{l}\text { Risiko } \\
\text { Kredit(X1) }\end{array}$ & $\begin{array}{c}\text { Profitabilitas } \\
\text { Tingkat }\end{array}$ & -6.327 & 0.000 \\
$\begin{array}{l}\text { Kecukupan } \\
\text { Modal(X2) }\end{array}$ & $\begin{array}{c}\text { Profitabilitas } \\
\text { (Y) }\end{array}$ & 5.648 & 0.000 \\
\hline
\end{tabular}

H2 diterima dimana nilai signifikan sebesar 0,000 lebih kecil dari 0,05, artinya ada pengaruh yang signifikan secara parsial antara CAR terhadap ROA penelitian ini sejalan dengan penelitian yang dilakukan Bernardin (2016) dimana nilai sig 0,021 lebih kecil dari tingkat signifikan 0,05 , sehingga tingkat kecukupan modal berpengaruh terhadap profitabilitas.

Tabel 2: Hasil Uji Simultan

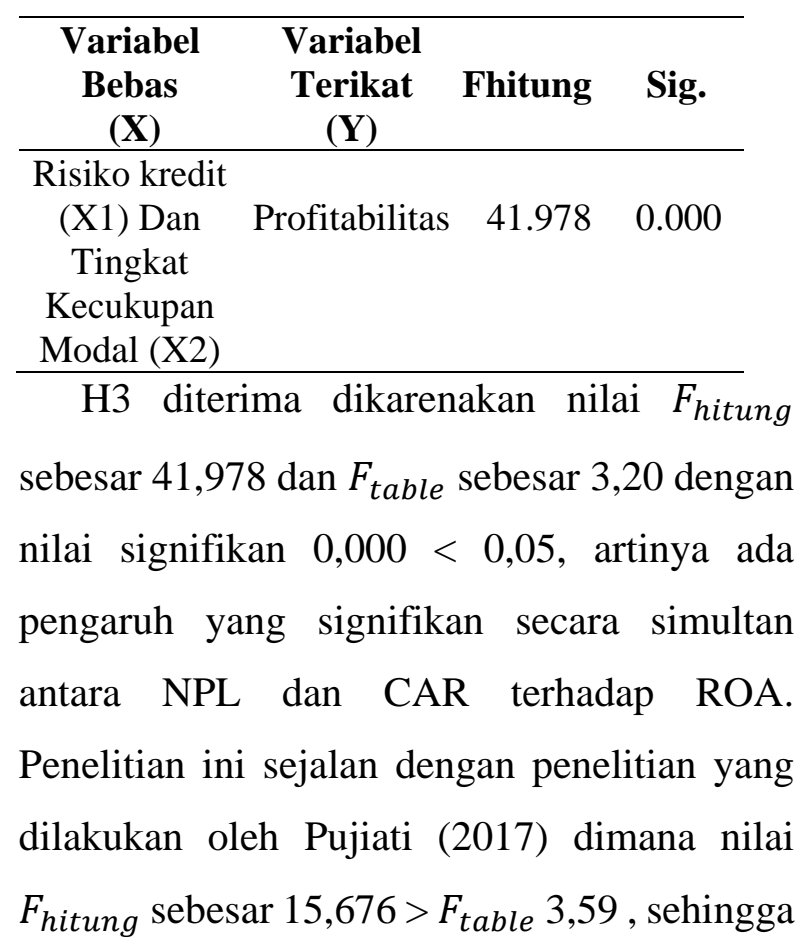

risiko kredit dan tingkat kecukupan modal berpengaruh terhadap profitabilitas.

H4 diterima dikarenakan berdasarkan perhitungan Sumbangan Efektif dengan presentase nilai Risiko kredit sebesar 35,5\% dan nilai Tingkat kecukupan modal sebesar $29,1 \%$.

Dimana Rumus Sumbangan Efektif sebagai berikut:

$\mathrm{SE}(\mathrm{X}) \%=$ Bet $_{x} \times$ koefisien korelasi $\times 100 \%$

Tabel 3: Hasil Perhitungan SE

\begin{tabular}{lcc}
\hline \multicolumn{1}{c}{ Variable } & Nilai & R Square \\
\hline Risiko & 35.5 & \\
Kredit & & 64.6 \\
$\begin{array}{l}\text { Tingkat kecukupan } \\
\text { Modal }\end{array}$ & 29.1 & \\
\hline
\end{tabular}

Berdasarkan dari perhitungan tersebut tentu dapat disimpulkan dimana faktor yang paling dominan antara risiko kredit dan Tingkat kecukupan modal pada profitabilitas ialah risiko kredit, dimana hal ini sejalan dengan penelitian Muniarty (2017) yang mengatakan bahwa variabel independent NPL yang paling dominan berpengaruh dengan nilai koefisien determinasi sebesar 60,20\%.

\section{SIMPULAN DAN SARAN}

\section{Simpulan}

Berdasarkan hasil pengujian hipotesis yang telah dilakukan maka kesimpulan pada penelitian ini:

1. Non Performing Loan (NPL) berpengaruh signifikan secara parsial terhadap Return on asset (ROA). 
2. Capital Adequacy Ratio (CAR) berpengaruh signifikan secara parsial terhadap Return On Asset (ROA).

3. Non Performing Loan (NPL) dan Capital adequacy ratio (CAR) berpengaruh signifikan secara simultan terhadap Return On Asset (ROA).

4. Dari kedua variabel independen (NPL dan CAR) terhadap variabel dependen (ROA) diketahui bahwa variabel independen (NPL) yang paling dominan berpengaruh terhadap variabel dependen (ROA)

\section{Saran}

Bagi penelitian selanjutnya diharapkan untuk menambahkan beberapa variabel yang tidak termasuk dalam penelitian ini. Secara internal dan eksternal manajemen sebaiknya bank lebih selektif lagi di dalam menarik calon debitur dan plafon agunannya.

Bagi perbankan yang terdaftar di BEI untuk tetap mempertahankan posisi presentase performa risiko kredit serta kecukupan modal.

\section{DAFTAR PUSTAKA}

Anggreni, M. R., \& Suardhika, I. M. S. (2014). Pengaruh dana pihak ketiga, kecukupan modal, risiko kredit dan suku bunga kredit pada profitabilitas. E-Jurnal Akuntansi Universitas Udayana, 9(1), 27-38.

Anjani, D. A., \& Purnawati, N. K. (2014). Pengaruh Non Performing Loan (NPL), Likuiditas dan Rentabilitas Terhadap Rasio Kecukupan Modal. Udayana University.

Bernardin, D. E. Y. (2016). Pengaruh CAR dan LDR terhadap Return on Assets. Jurnal
Ecodemica: Jurnal Ekonomi, Manajemen, Dan Bisnis, 4(2), 232-241.

Edy, C. waskito. (2019a). No Title. Tribun Jateng.

Edy, C. waskito. (2019b). Rasio Kredit Bermasalah di Indonesia Meningkat, Tertinggi Kedua di Asia Tenggara. Tribun Jateng. https://jateng.tribunnews.com/2019/12/2 6/rasio-kredit-bermasalah-di-indonesiameningkat-tertinggi-kedua-di-asiatenggara

Firdaus, R., \& Maya, A. (2009). Manajemen Perkreditan Rakyat Umum. Alfabeta.

Herlina, H., Nugraha, N., \& Purnamasari, I. (2016). Pengaruh Risiko Kredit Terhadap Profitabilitas (Studi Kasus Pada Bank Umum Swasta Nasional Devisa Tahun 2010-2014). Journal of Business Management Education (JBME), 1(1), 31-38. https://doi.org/10.17509/jbme.v1i1.2276

Mendoza, R. R., \& Rivera, J. P. R. (2017). The effect of credit risk and capital adequacy on the profitability of rural banks in the Philippines. Scientific Annals of Economics and Business, 64(1).

Muniarty, P. (2017). Analisis Pengaruh CAR, NPL, PDN, LDR dan Suku Bunga SBI Terhadap ROA (Studi Pada Bank Devisa Yang Listed Di BI Periode Tahun 20032009). ETIS Versi Cetak, 1(2), 123-179.

Negara, I., Atmaja, P. A., \& Sujana, I. K. (2014). Pengaruh Capital Adequacy Ratio, Penyaluran Kredit dan Non Performing Loan Pada Profitabilitas. Fakultas Ekonomi Dan Bisnis Universitas Udayana.

Pratiwi, E. R. I. (2016). Pengaruh Risiko Kredit dan Tingkat Kecukupan Modal terhadap Profitabilitas Perbankan yang Terdaftar di Bursa Efek Indonesia. STIE PERBANAS SURABAYA. 
Nominal: Barometer Riset Akuntansi dan Manajemen

P-ISSN: 2303-2065 E-ISSN: 2502-5430

Volume 10 No 2 (2021)

Pujiati, H. (2017). Pengaruh Risiko Kredit dan Tingkat Kecukupan Modal terhadap Profitabilitas pada Perusahaan Perbankan Sektor BUMN yang Terdaftar di BEI Periode 2012-2016. Aktiva-Jurnal Penelitian Ekonomi Dan Bisnis, 1(1).

Said, S. (2016). Pengaruh Risiko Kredit Dan Tingkat Kecukupan Modal Terhadap Profitabilitas Pada Perbankan Di Bursa Efek Indonesia. Jurnal Minds: Manajemen Ide Dan Inspirasi, 3(2), 7693.

Septiani, R., \& Lestari, P. V. (2016). Pengaruh NPL dan LDR terhadap Profitabilitas dengan CAR sebagai variabel mediasi pada PT BPR pasarraya kuta. Udayana University.

Sinaga, E. (2019). Pengaruh kecukupan modal terhadap profitabilitas bank umum di Indonesia tahun 2012-2017.

Siyoto, S., \& Sodik, M. A. (2015). Dasar metodologi penelitian. Literasi Media Publishing.

Sugiono. (2016). Metode Penelitian Pendidikan Pendekatan Kuantitatif, Kualitatif dan $R \& D$. Alfabeta.

Suharsimi, A. (2006). Prosedur penelitian suatu pendekatan praktik. Jakarta: Rineka Cipta, 120-123. 